\title{
Defective yeast opsonisation and functional deficiency of complement in sickle cell disease
}

\author{
V F LARCHER, R J WYKE, L R DAVIS, C E STROUD, AND ROGER WILLIAMS
}

Department of Child Health, Department of Paediatric Pathology, and the Liver Unit, King's College Hospital Medical School, London

SUMMARY Opsonisation of heat-killed baker's yeast, functional activity of the total alternative pathway of complement, and factor B detected functionally and immunochemically were significantly reduced in 72 children with sickle cell disease compared with 40 age-matched black control children. There was significant correlation between functional activity of the total alternative pathway and functionally measured factor B, but not between factor B measured functionally and immunochemically. The opsonisation defect could be corrected in vitro by normal serum, and factor Bdepleted serum, and was qualitatively similar to that seen in patients with primary yeast opsonisation deficiency. Serial studies showed that these serum defects were persistent. Reduction in the activity of components of the alternative pathway of complement and opsonisation was found in 4 patients who had recovered from pneumococcal meningitis and in one who developed osteomyelitis. Defects of yeast opsonisation and complement which are common in patients with sickle cell disease, may partly explain the children's increased susceptibility to infection, and might help to identify individuals especially at risk.

Patients with sickle cell disease (SCD) have an increased incidence of pneumococcal and Gramnegative infection; ${ }^{12}$ the precise reasons for this have not been established. Opsonisation of bacteria by serum factors including complement and immunoglobulin is an important host defence mechanism which, in the absence of specific immunoglobulin, depends on activation of the alternative pathway of complement. Functional defects in this pathway, including factor $\mathrm{B}^{3}$ have been associated with defective pneumococcal opsonisation ${ }^{4}$ in patients with SCD, although levels of immunochemically measured factor $B$ are normal. ${ }^{5}$

Opsonisation of heat-killed baker's yeast is a further test of the integrity of the alternative pathway, ${ }^{6}$ but is only partially dependent on factor B. ${ }^{7}$ Since defects are associated with an increased incidence of infection, ${ }^{8}$ we measured ability of sera from patients with SCD to opsonise yeasts, and the relation to functionally and immunochemically measured factor B and activity of the total alternative pathway of complement. The incidence of pneumococcal infection in these patients was analysed retrospectively.

\section{Patients and methods}

Seventy-two ( 37 boys and 35 girls; mean age $8 \cdot 5$ years, range $0 \cdot 5-16)$ children were studied. All had SCD proved by positive sickle cell test, typical blood film, and haemoglobin electrophoresis; 70 were homozygous for haemoglobin $\mathbf{S}$ and 2 had haemoglobin SC. All were seen at the Sickle Cell Anaemia Clinic at the Belgrave Hospital for Children, London. None of the patients had infection or crisis; none had received blood transfusion within the preceding 2 weeks. There were 28 siblings from 13 families with homozygous SS disease; 7 patients were studied more than once during the course of 6 months.

Control sera were obtained from 40 normal healthy black children ( 22 boys, 18 girls; mean age 7.4 years, range $1-14$ ) with normal haemoglobin electrophoresis but without history of recurrent infection or allergy, in whom venepuncture was necessary for their management. Venous blood was allowed to clot for 2 hours at room temperature; serum was separated and stored in aliquots at $-70^{\circ} \mathrm{C}$, being thawed once immediately before use.

Functional activities of the total alternative pathway of complement and factor B were assayed by radial haemolytic diffusion in agarose; 9 concentration of immunoreactive factor $B$ was measured by immunodiffusion against specific antiserum. All results were expressed as a percentage of normal serum pool included as controls. 
Opsonisation of heat-killed baker's yeast was measured by a Coulter Counter technique. ${ }^{10}$ Results were expressed as the percentage of yeasts phagocytosed.

Statistical significance of differences between normally distributed data was analysed by Student's $t$ test; for non-parametrically distributed data, differences were analysed by Wilcoxon's rank sum test.

\section{Results}

Yeast opsonisation. The mean percentage of yeasts phagocytosed (49 \pm SD 10.5\%) for sera from black controls did not differ significantly $(P>0.5)$ from that in 25 age-matched white children $(50 \pm \mathrm{SD}$ $10 \%$ ). The overall incidence of defective opsonisation was similar in black and white controls, with values of 5 and $4 \%$ respectively. In contrast, 11 (15\%) of 72 children with sickle cell disease had defective opsonisation (Figure)

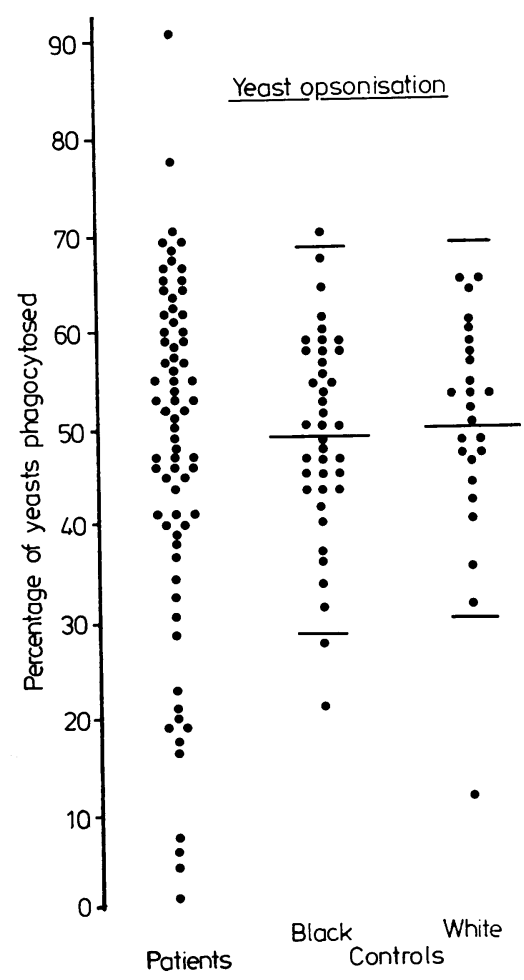

Figure Percentage of yeasts phagocytosed by normal polymorphonuclear leucocytes in the presence of $5 \%$ serum from patients with sickle cell disease and black and white controls. Means $\pm 2 S D$ for controls are shown.
Table 1 Complement components, as percentage of control serum pool, in serum from patients with sickle cell disease and in controls

\begin{tabular}{lccl}
\hline Subjects & $\begin{array}{l}\text { Total } \\
\text { alternative } \\
\text { pathway } \\
\text { activity }\end{array}$ & $\begin{array}{l}\text { Functional } \\
\text { factor } B\end{array}$ & $\begin{array}{l}\text { Immuno- } \\
\text { chemical } \\
\text { factor } B\end{array}$ \\
\hline Patients $(\mathrm{n}=72)$ & $89 \pm 35$ & $95 \pm 32$ & $103 \pm 32$ \\
Controls $(\mathrm{n}=40)$ & $105 \pm 25$ & $141 \pm 40$ & $126 \pm 40$ \\
P value & $<0.01$ & $<0.005$ & $<0.05$ \\
\hline
\end{tabular}

Values given as mean $\pm \mathrm{SD}$.

Complement studies. The mean activity of the total alternative pathway of complement in sera from patients with SCD was significantly reduced compared with controls (Table 1). In 25 patients and 1 control, activity was below 2 SD of the control mean.

Functional activity of factor B was also reduced (Table 1) with values in 9 patients less than 2 SD of the control mean. Sera from these 9 patients also had significant reduction in activity of total alternative pathway. There was a significant $(r=$ $0.53, \mathrm{P}<0.01)$ positive correlation between functional activities of the total alternative pathway and factor $\mathrm{B}$.

Factor B was also significantly reduced when measured immunochemically (Table 1); 6 patients and 1 control had values less than 2 SD of the control mean. There was no significant correlation $(r=0.187, P \geqslant 0.1)$ between levels of factor $B$ measured functionally and immunochemically. Eight patients with functional deficiency of factor B had normal serum levels of factor $B$ when measured immunochemically.

Five of the 11 patients with yeast opsonisation deficiency had reduced activity of the alternative pathway, but none had deficiency of factor B whether measured functionally or immunochemically. Opsonisation and complement deficiencies were not related to the patient's age, sex, or haemoglobin type. Two patients with serum defects (total alternative pathway and factor B activity in one, yeast opsonisation in the other), showed no change in the defect in serial studies during the course of 6 months. None of the 5 patients studied with normal serum opsonisation or complement developed abnormalities during this period.

No consistent familial pattern of deficiencies could be identified among the 28 siblings from 13 families, although siblings in some families with complement deficiency had low normal values (less than 2 SD but more than 1.5 SD below the control mean).

Nature of opsonisation defect. The effect of adding 
Table 2 Effect of adding $0.5 \%$ concentration of various sera on opsonisation capacity of $5 \%$ sickle cell disease sera with opsonisation deficiency and primary opsonisation deficiency sera

\begin{tabular}{|c|c|c|c|c|c|}
\hline \multirow[t]{2}{*}{$\begin{array}{l}\text { Source of } \\
5 \% \text { serum }\end{array}$} & \multirow[t]{2}{*}{$\begin{array}{l}\text { No } \\
\text { additive }\end{array}$} & \multicolumn{4}{|c|}{$\begin{array}{l}\text { Percentage (mean } \pm \text { SEM) of yeasts } \\
\text { phagocytosed after addition of } 0.5 \%\end{array}$} \\
\hline & & $\begin{array}{l}\text { Of } \\
\text { normal } \\
\text { serum }\end{array}$ & $\begin{array}{l}\text { Of B- } \\
\text { depleted } \\
\text { serum }\end{array}$ & $\begin{array}{l}\text { Of } S C D \\
\text { serum } \\
\text { with } \\
\text { factor } B \\
\text { deficiency }\end{array}$ & $\begin{array}{l}\text { Of serum } \\
\text { with } 1^{\circ} \\
\text { opsonisa- } \\
\text { tion } \\
\text { deficiency }\end{array}$ \\
\hline
\end{tabular}

\begin{tabular}{lccccc}
\hline $\begin{array}{l}\text { Sickle cell } \\
\text { disease }\end{array}$ & $12 \pm 3.5$ & $33 \pm 3.0$ & $28 \pm 3.5$ & $25 \pm 4.9$ & $13 \pm 3.9$ \\
10 opsonisation & & & & & \\
deficiency & $16 \pm 3.2$ & $42 \pm 4.2$ & $38 \pm 2.9$ & $25 \pm 3.7$ & $19 \pm 2.5$ \\
Buffer alone & 0 & $8 \pm 2.2$ & $5 \pm 1.7$ & $2 \pm 0.9$ & $4 \pm 1.0$ \\
\hline
\end{tabular}

Values represent mean \pm SEM of 4 experiments with 4 sera.

various sera to those from defective patients with sickle cell disease and patients with primary yeast opsonisation deficiency was investigated to compare the nature of the yeast opsonisation defect in the two groups. Percentage of yeasts phagocytosed in the presence of the serum mixtures was determined in the normal way. Results are shown in Table 2. The opsonisation defect in sera from patients with SCD was corrected by addition of low concentrations $(0.5 \%)$ of normal serum, normal serum depleted in factor B, or serum from patients with SCD with a factor B activity of less than half that of normal. All these sera produced similar qualitative improvement in opsonising capacity of sera from patients with primary opsonisation deficiency, but alone in a $0.5 \%$ concentration in buffer they were not opsonic (Table 2). Sera from patients with a primary defect of yeast opsonisation did not correct the opsonisation deficiency in sera from patients with SCD.

Relationship with pneumococcal infection. Four patients studied had recovered from pneumococcal meningitis between 2 and 11 years previously. All had reduced activity of the alternative pathway, two had a functional deficiency of factor $B$, and two had defective yeast opsonisation. Since the present study began, one child with deficiency of the alternative pathway and factor $B$ has developed septic arthritis and osteomyelitis owing to Klebsiella sp.

\section{Discussion}

Inability of serum to opsonise heat-killed baker's yeast was three times more common in patients with SCD than in healthy black or white controls, in whom the incidence of deficiency was similar to that previously reported. ${ }^{810}$ Factor $\mathrm{B}$ activity is required for opsonisation of yeasts ${ }^{7}$ and was reduced, in association with total alternative pathway activity, in patients with SCD. However, low levels of factor
B were not responsible for defective yeast opsonisation, since subopsonising amounts of normal sera depleted of factor B or sera from patients deficient in factor B could correct the opsonisation defect. The finding of normal yeast opsonisation in all 9 $(12 \%)$ of patients with deficiency of factor $B$ activity also implies that the two defects are distinct. Similarly, correction of opsonisation by subopsonising amounts of normal sera but not by sera from patients with primary deficiency states suggests that defective opsonisation of yeast by sera from patients with SCD is qualitatively similar to that seen in primary deficiency states. Since defects in opsonisation and factor $B$ activity probably represent separate, specific defects in the alternative pathway of complement, failure to identify either in 11 of 25 of those with a defect in total alternative pathway activity implies that other defects in this pathway may occur in SCD. However, evidence for deficiencies of other components-for example, factor $\mathrm{D}$-is conflicting ${ }^{311}$ and requires further study. We found, unlike Bjornson et al., ${ }^{5}$ that levels of immunochemically measured factor $B$ were lower than controls, but could demonstrate no significant correlation between functionally and immunochemically measured factor B, presumably because simple immunochemical measurements cannot distinguish between functionally active and inactive complement. This lack of correlation may explain the normal opsonisation of pneumococci by sera defective in immunochemical factor $\mathbf{B},{ }^{5}$ since opsonisation of pneumococci is presumably a functional measure of factor B activity. ${ }^{4}$

Although primary or congenital deficiency states cannot be excluded as a cause of the observed defects in opsonisation and complement, a more likely explanation is that the deficiencies were secondary. Correction of opsonisation by subopsonising amounts of normal serum excludes the presence of an inhibitor. Both excessive consumption and failure of synthesis of functionally active complement could have produced the defects. Red cell stroma can activate the alternative pathway thereby consuming complement, ${ }^{12}$ but no patients had recent haemolytic episodes and $\mathrm{C} 3$ split products (C3d) have not been detected in a limited number of plasma samples so far examined (Vergani, personal communication). Failure to synthesise complement might follow blockade of the reticuloendothelial system by abnormal erythrocytes. Since reticuloendothelial cells are a major site of complement synthesis ${ }^{13}$ blockade of this system, which may occur in SCD in the absence of painful crisis, ${ }^{14}$ might influence complement synthesis.

Both deficiency of yeast opsonisation ${ }^{8}$ and factor $B^{4}$ have been associated with an increased incidence 
of infection and retrospective analysis of our cases would support such an association. Pneumococcal infection remains a major cause of mortality and morbidity in young children with $\mathrm{SCD}^{15}$ and accounted for 4 of 199 admissions of all age groups in a recent UK study. ${ }^{16}$ Immunisation with a polyvalent vaccine and penicillin prophylaxis have been advocated as effective means of preventing pneumococcal infection in patients with SCD but both are expensive. ${ }^{15}$ Our data suggest that screening of patients for complement and opsonisation defects might identify individuals especially at risk from pneumonococcal infection. Although immunochemical assays are fairly cheap and easy to perform our data suggest that the more time-consuming functional assays should be used for this purpose.

We thank Miss J I Silk for valuable assistance and the support of Immuno is gratefully acknowledged.

\section{References}

1 Robinson M G, Watson R J. Pneumococcal meningitis in sickle-cell anemia. $N$ Engl J Med 1966; 274: 1006-8.

2 Seeler R A, Metzger W, Mufson M A. Diplococcus pneumoniae infections in children with sickle cell anemia. Am J Dis Child 1972; 123: 8-10.

3 Wilson W A, Hughes G R V, Lachmann P J. Deficiency of factor $\mathrm{B}$ of the complement system in sickle cell anaemia. Br Med J 1976; i: 367-9.

4 Johnston R B, Jr, Newman S L, Struth A G. An abnormality of the alternate pathway of complement activation in sickle cell disease. $N$ Engl $J$ Med 1973; 288: 803-8.

5 Bjornson A B, Gaston M H, Zellner C L. Decreased opsonization for streptococcus pneumoniae in sickle cell disease. Studies on selected complement components and immunoglobulins. $J$ Pediatr 1977; 91: 371-8.
6 Soothill J F, Harvey B A M. A defect in the alternative pathway of complement. J Clin Exp Immunol 1977; 27: 30-3.

7 Larcher V F, Wyke R J, Mowat A P, Williams R. Mechanism of the yeast opsonisation defect in patients with fulminant hepatic failure. Clin Exp Immunol 1981; 46: 406-11.

8 Soothill J F, Harvey B A M. Defective opsonisation; a common immunity deficiency. Arch Dis Child 1976; 51: 91-9.

9 Martin A, Lachmann P J, Halbwachs L, Hobart M J. Haemolytic diffusion plate assays for factor B and D of the alternative pathway of complement activation. Immunochemistry 1976; 13: 317-24.

10 Levinsky R J, Harvey B A M, Paleja S. A rapid objective method for measuring the yeast opsonisation activity of serum. J Immunol Methods 1978; 24: 251-6.

11 Koethe S M, Casper J T, Rodney G E. Alternative complement pathway activity in sera from patients with sickle cell disease. Clin Exp Immunol 1976; 23: 56-60.

12 Poskitt T R, Fortwengler H P, Jr, Lunkis B J. Activation of the alternate complement pathway by autologous red cell stroma. J Exp Med 1973; 138: 715-22.

13 Whaley K. Biosynthesis of the complement components and the regulatory proteins of the alternative complement pathway by human peripheral blood monocytes. $J$ Exp Med 1980; 151 : 501-6.

14 Rosenblate H J, Eisenstein R, Holmes A W. The liver in sickle cell anemia. Arch Pathol 1970; 90: 235-45.

15 Rogers D W, Clarke J M, Cupidore L, Ramlal A M, Sparke B R, Serjeant G R. Early deaths in Jamaican children with sickle cell disease. Br Med J 1978; i: 1515-6.

16 Anionwu E, Walford D, Brozovic M, Kirkwood B. Sickle cell disease in a British urban community. $\mathrm{Br}$ Med $\mathrm{J}$ 1981; 282: 283-6.

Correspondence to Dr V F Larcher, Department of Child Health, King's College Hospital Medical School, Denmark Hill, London SE5 8RX.

Received 2 November 1981 